DOI: https://doi.org/10.31933/dijemss.v2i2

Received: $15^{\text {th }}$ October 2020, Revised: $15^{\text {th }}$ November 2020, Publish: $15^{\text {th }}$ December 2020

\begin{tabular}{|c|c|c|}
\hline PINASTISTER & $\begin{array}{l}\text { DIJEMSS } \\
\text { DINASTI INTERNATIONAL JOURNAL } \\
\text { OF EDUCATION MANAGEMENT AND } \\
\text { SOCIAL SCIENCE }\end{array}$ & $\begin{array}{r}\text { https://dinastipub.org/DIJEMSS } \\
\text { editor@dinastipub.org } \\
081174014550\end{array}$ \\
\hline
\end{tabular}

\title{
ENTREPRENEURIAL PASSION, ENTREPRENEURIAL ALERTNESS AND ISLAMIC ENTREPRENEURIAL ORIENTATION: ITS APPLICATION TO THE MUSLIMAH ENTREPRENEUR
}

\author{
Suswita Roza', Yayuk Sriayudha ${ }^{2)}$, Ade Octavia ${ }^{3)}$ \\ ${ }^{1}$ Faculty of Economic and Business, Universitas Jambi, Indonesia, susieroza@yahoo.com \\ ${ }^{2}$ Faculty of Economic and Business, Universitas Jambi, Indonesia, yayuksriayudha@ gmail.com \\ ${ }^{3}$ Faculty of Economic and Business, Universitas Jambi, Indonesia, octaviafebunja@gmail.com \\ Corresponding author: Suswita Roza ${ }^{1}$
}

\begin{abstract}
The success of an entrepreneur orientation from an Islamic perspective is not only measured in material success but also in a growing business. Muslimah entrepreneur needs passion and alertness in entrepreneurship to help to shape an entrepreneurial optimism and make decisions as well as business development efforts. The aims of the research are (1). Analyzing the influence of entrepreneurial passion on entrepreneurial alertness (2). Analyzing the influence of entrepreneurial alertness on Islamic entrepreneurial orientation (3). Analyzing the influence of entrepreneurial passion on Islamic entrepreneurial orientation. Data were collected from a sample of 86 Muslimah entrepreneurs from the Association of Muslimah Entrepreneurs in Jambi Province. Data collection is carried out using a questionnaire as the instrument research. Moreover, path analysis is used to analyze the influence of each variable studied. The results showed that there is a positive and significant influence between: entrepreneurial passion on entrepreneurial alertness, entrepreneurial alertness on Islamic entrepreneurial orientation, and entrepreneurial passion on the Islamic entrepreneurial orientation of Muslimah entrepreneurs. Research implementation will enhance the passion and alertness of Muslimah entrepreneurs and it suggests further studies to strengthen the model of research particularly in terms of Islamic entrepreneurship perspective.
\end{abstract}

Keywords: Entrepreneurial Passion, Entrepreneurial Alertness, Entrepreneurial Orientation, Muslimah Entrepreneur

\section{INTRODUCTION}

The term entrepreneurial orientation means how the owner of a business has an entrepreneurial spirit and culture. It is defined as the ability of an organization to discover and make any possible opportunities to gain access to enter a new market. Entrepreneurial orientation comes from strategic processes that reflect policy and decision-making actions 
(Lumpkin and Des, 1996 ; Rauch et al., 2009). Entrepreneurial orientation is characterized by five dimensions including innovation, risk-taking, pro-activeness, competitive aggressiveness and autonomy. Entrepreneurs who apply the concept of entrepreneurial orientation will get optimal business performance. The study found the higher the level of entrepreneurial orientation the higher the business performance to be achieved (Kreiser and Davis, 2010; Mahmood and Hanafi, 2013; Octavia and Hapszi, 2017)). Organizations that are efficiently entrepreneurialoriented deserve to be rewarded for their efforts to run entrepreneurship (Boohene, 2018).The concept of Islamic entrepreneurial orientation is a new concept that will be observed in this study. The indicators lead is fixed to entrepreneurial orientation activity but carried out by Muslim entrepreneurs based on Islamic rules. As a religion that emphasizes strongly about its doctrinal principles, Islam considers that trade or entrepreneurship is an activity that allows as long as it remains in the Syariah corridors of the Islamic way of life. Successful entrepreneurs from the Islamic side are not only measured in terms of success materially. This is because human needs are not only for property needs but there are other necessary aspects concerning religion, intelligence, life, honor (Yaacob and Azmi, 2012). Related to this in entrepreneurial islamic entrepreneurs are not only profit-oriented but also produce halal goods and services.Chowdhury (2008) and Hoque et al (2014) stated that Muslim entrepreneurship is the process of starting from a company to produce halal goods and services and generate reasonable profits.

Over the last decade, women's participation as an entrepreneur has increased quite sharply. The number of women entrepreneurs across the world has been growing in the recent years. More researchers have been paying more attention to women entrepreneurship (Sarfaraz et al, , 2014). Women's role as entrepreneurs had become more significant in both developed and developing countries. In Indonesia, the number of SMEs managed by women is gradually increasing. In 2017, the number of women working as entrepreneurs was 14.3 million people, an increase of 1.6 million compared to 12.7 million in 2015 (tribunnews.com.2019). The unique and distinctive character of a woman makes many women prefer to set up a business (Miftakhuljanah et $\mathrm{al}, 2016)$. The increase in the number of female entrepreneurs is due to strong motivation to progress and higher levels of education. (Gupta \& Mirchandani, 2018) found that encouragement and attraction are motivation and commitment of a woman to become an entrepreneur. Muslimah entrepreneurs are women entrepreneurs who running or having businesses. In carrying out its business, business entrepreneurs, especially Muslimah, must be vigilant and alert to become involved in carrying out un-Islamic business practices (Fatoki and Oni, 2015). Entrepreneurial alertness refers to a sense of paying attention to what is possible to identify opportunities. This is important because the ability to read business opportunities is an important factor for business success (Tang et al, 2012).

The early-stage for direct and create business is a passion inside. Passion is a strong tendency towards an activity where a person feel like, finds importance, and eager to invest significantly in time and energy (Cardon et al, 2017). Increasing research shows that passion as a key important aspect of entrepreneurship and it has a crucial role in the business creation both process and outcomes ( Karimi 2019 ; Huyghe, et al 2016). Entrepreneurial passion reflects the main characteristic that an entrepreneur has which is a result of entrepreneurial behavior (Karimi, 2019). The dimensions of entrepreneurial passion include intense positive feelings and the centrality of identity. This passion will shape entrepreneurial optimism related to entrepreneur 
scoring and decision-making about their new ventures (Koudstaal et al, 2015; Chen et al, 2017). Although entrepreneurial habits are essential for business creation and growth (Cardon et al.2009; Biraglia and Kadile, 2016), many interesting questions began to unravel about the passion of entrepreneurship, how and to what extent entrepreneurial passion and entrepreneurial alertness can develop and influence the orientation of entrepreneurship in society. Tang et al (2012) ; Fatoki \& Oni (2012) observed the ability of individuals to identify opportunities in business is also an important key. How entrepreneurs have the ability to search for new information, associate each information and evaluate new information. Muslimah entrepreneurs decided to enter the world of entrepreneurship because they have a certain passion. Knowing what passion they have in running entrepreneurship will force entrepreneurs to gain information related to the business. This information is useful to support the decision-making process within an organization.

\section{THEORETICAL FRAMEWORK \\ Entrepreneurial Passion and Entrepreneurial Alertness}

Passion in entrepreneurship is an important characteristic that entrepreneur must have. Entrepreneurs who have passion for running business feel comfort about their identity as the founder of the business and considers that being a founder is part of the important side to themselves. Furthermore, Cardon et al. (2009) conceptualized entrepreneurial passion as a conscious state that can be accessed by intense positive feelings experienced through involvement in entrepreneurial activities related to a meaningful role for the entrepreneur's identity. Costa et al (2017) reviewed passion in entrepreneurship has been defined as awareness and intensity that can be accessed with positive feelings in typical entrepreneurial activities. Many studies in which researchers have found that positive entrepreneurial optimism is associated with entrepreneurial judgment and decision-making about their new ventures (Koudstaal et al., 2015; Chen et al 2017). The main part of activities has the potential to be a positive passion instead of obsessive passion. According to Vallerand (2003) and Karimi (2019) passion is a burning desire, strong belief and drive that makes people disciplined to achieve their vision. A person's dream can be realized if he or she has a passion and an intention to make it happen. A strong passion for entrepreneurship will create a sensitivity that refers to the ability to read what might be an opportunity out there. As explained earlier, the passion for entrepreneurial activities in certain contexts can trigger context-related business startup planning (Biraglia and Kadile, 2016). When entrepreneurs getting involved in a new thing, passion appears as an emotion to influence vision, mission, and decision in process of planning. Based on the above arguments it can be inferred that:

$\mathrm{H} 1$ : There is a positive and significant influence between entrepreneurial passion and entrepreneurial alertness.

\section{Entrepreneurial Alertness and Islamic Entrepreneurial Orientation}

Fatoki and Oni (2015) stated that alertness is an individual's ability to identify unknown or overlooked opportunities. Alertness refers to a sense of paying attention and sensitive to what is possible in business. An insensitive entrepreneur is different from a sensitive entrepreneur. Unvigilant entrepreneurs can't identify opportunities because they don't rate the market environment well. Tang et al (2012) found that the innovation and development of SMEs is the result of an entrepreneurial process in which if new market opportunities are seen, plans can be 
developed and executed to exploit opportunities. The concept of entrepreneurial alertness has evolved, embracing a aproactive attitude based on knowledge and experience, pattern recognition, skills in information processing, and the development of social interaction ( Tang et al, 2012; Lee et al, 2016). The passion for creating value and making an impact is fundamental to the nature of entrepreneurs. The creation of new businesses occurs over time and the first stage of this process is the establishment of entrepreneurial intentions, indicating a behavioral dimension. Furthermore, entrepreneurial intentions reflect an individual's interest in starting a business and in choosing alternative career routes for ordinary jobs.

Muslim/Muslimah entrepreneurs are people who start and manage business companies following Islamic guidelines. Muslimah employers carefully avoid unwanted hoarding, mistreated of employees and unfair dealing with customers. Profit-seeking is not the only goal of Islamic entrepreneurship. On the contrary, income from divided satisfaction, social welfare and the protection of the national interest is the driving force of such entrepreneurship (Chowdhury, 2008; Hoque et al, 2014). To overcome competitor challenges as well as identify business opportunities from a volatile environment and thus make the organization successful, entrepreneurs must think strategically. The sensitivity of reading opportunities that create global excellence through culture and religion is a situation that should be for every organization. The goal is to see the ins and outs of the general market and the Muslim market in particular so as to be able to lead the global market strategically. It is logical from the above explanation to predict that entrepreneurial alertness influence Islamic entrepreneur orientation. Thus:

$\mathrm{H} 2$ : There is a positive and significant influence between entrepreneurial alertness and Islamic entrepreneurial orientation.

\section{Entrepreneurial Passion dan Islamic Entrepreneurial Orientation}

Passion desire to act and behave entrepreneurially and bind entrepreneurs to achieve entrepreneurial goals (Tasnim et al, 2014 ; Merieska and Meiyanto, 2017 ). Passion tends to mobilize the energy that would-be entrepreneurs need to cope with challenging situations by dealing with uncertainty (Biraglia and Kadile, 2016). Passion is also a strong tendency towards preferred activities in the core aspect of one's self. To move one's heart in doing something that is liked and or achieving a goal requires motivation. By understanding the dynamics of passion in business, young entrepreneurs can understand the importance of the role of passion. This efforts can certainly avoid failure in business. A Muslim/Muslimah entrepreneurs has a strong motivation for the development and they are considered to the ones who fights in the way of Allah. According to Yaacob and Azmi (2012), a successful Muslim-being in this world and the afterlife is a Muslim who has a strong economy for himself and can contribute to society. Islamic entrepreneurship ensures consumer rights, social responsibility, ethical values and healthy business practices (Chowdhury, 2008). Entrepreneurial passion can build an effective thing and can sometimes help overcome certain obstacles associated with the establishment of a new business. Thus the hypothesis of the third studies is:

$\mathrm{H} 3$ : There is a positive and significant influence between entrepreneurial passion and Islamic entrepreneurial orientation. 
The research model in Figure 1 aims to create an understanding among entrepreneurial passion, entrepreneurial alertness and Islamic entrepreneurial orientation of Muslimah entrepreneurs. All the research hypotheses summarized by the following model :
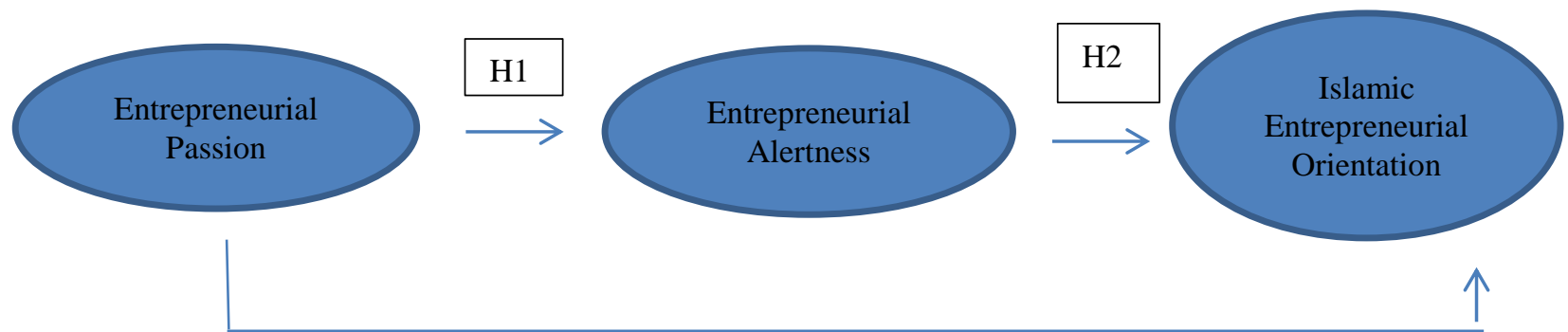

H3

Figure 1. Conceptual Framework

\section{METHOD}

This study used a survey research design. The quantitative data were acquired through a structured questionnaire for Muslimah entrepreneurs. The qualitative data were gained through articles, journals, electronic media, and other related literature. The questionnaire was sent to respondence by email and google form and it divided into three parts 1) Entrepreneurial passion, 2) entrepreneurial alertness and 3) Islamic entrepreneurial orientation. The five-point Likert scale ranging from strongly disagree to strongly agree. The sampling frame for this study consisted of Muslimah entrepreneur that were listed in Muslimah Entrepreneur Association (IPEMI) in Jambi Province. There are 600 members joined in IPEMI. Those 600 members were randomly selected by the Slovin formula. Therefore, there are 86 members of Muslimah Entrepreneur Association as a sample of the research. The Slovin formula is a formula used to calculate the minimum sample number of a limited population survey (finite population survey) where the main purpose of the survey is to estimate the proportion of the population (Tejada and Punzalan, 2012). This study used a Path analysis to analyze the influence of each variable. The purpose of using path analysis is to explain why variables correlate by using a temporary sequential model, drawing and testing a mathematical model using the underlying equation, identifying the causal path of a particular variable against another variable it affects and calculating the influence of one or more exogenous independent variables on other endogenous dependent variables.

\section{RESULT AND DISCUSSION}

Data were descriptively analyzed by the statistical package of SPSS 21 version and the following table related explain with the respondence characteristics from several points of view :. 
Table 1. Respondents Characteristic

\begin{tabular}{cccc}
\hline No & Characteristic & Range & Percentage \\
\hline 1 & Age & $<25$ years old & 23,3 \\
& $26-35$ years old & 34,9 \\
& $36-45$ years old & 22,1 \\
& $46-50$ years old & 12,8 \\
& & $>55$ years old & 7 \\
\hline 2 & Educational Backgroun & High School level & 23,3 \\
& & S1/Diploma Degree & 53,5 \\
& & Master/Doctoral Degree & 23,3 \\
\hline 3 & Position in Business & Founder/owner & 73,3 \\
& & Owner & 20,9 \\
& & Manager & 5,8 \\
\hline 4 & Type of Business & Culinary & 39,5 \\
& & Fashion & 25,6 \\
& & Manufacture & 0 \\
& & Others & 34,9 \\
\hline \multirow{2}{*}{5} & Number of Labor & $1-5$ people & 79,1 \\
& & $6-10$ people & 8,1 \\
& & $11-15$ people & 8,1 \\
& & $>16$ people & 4,7 \\
\hline
\end{tabular}

Source : Processed data 2020.

Based on the characteristic respondence in table 1, it showed that 34 percent of Muslimah entrepreneur is in the range of 26-35 years old and 23,3 percent are below 25 years old. The average age of Muslimah entrepreneur is in productive ages. Starting business in the early bird is giving more advantages since the opportunities to explore idea and experience is still widely open. At a young age one will adapt more quickly to new things so that it develops faster. According to the Global Data Entrepreneurship Monitor (2014), from 85 million productive women age in Indonesia, 26 percent of them are active entrepreneurs. Relevance situation to educational background revealed that 53,5 percent Muslimah entrepreneur is in productive age and 53,5 percent are having S1/Diploma Degree. In today's competitive era, education become important to enrich science and knowledge. Such intense business competition makes the younger generation feel "Well educated" and "action oriented". To be successful entrepreneurs today not only with courage and good fortune, but also must be accompanied by educated souls and minds in order to be more precise in making the right decisions. 
Moreover, 73,3 percent of Muslimah entrepreneurs are the founder as well as the owner ob business. Having their own business makes it easier for entrepreneurial women to develop dreams of growing a business. Struggling to set up your own business makes someone rich in experience and maximizes self-potential. Muslimah entrepreneurs tend to select a running business based on certain engagement. Muslimah entrepreneurs prefer to pursue culinary as a potential business because it close to daily activities. Women choose to pursue this type of business because it is considered close to their daily life as housewives. Armed with creativity and innovation culinary business becomes a popular business and is widely pursued by young people.

Table 2. Data Analysis and Result

\begin{tabular}{|c|c|c|c|c|c|c|c|c|c|}
\hline \multirow{2}{*}{ Model } & & \multicolumn{2}{|c|}{$\begin{array}{l}\text { Unstandardized } \\
\text { Coefficients }\end{array}$} & \multirow{2}{*}{$\begin{array}{c}\text { Standardized } \\
\text { Coefficients } \\
\text { Beta }\end{array}$} & \multirow{2}{*}{$\mathrm{R}$} & \multirow{2}{*}{ R Square } & \multirow{2}{*}{$\begin{array}{l}\text { Adjusted } \\
\text { R Square }\end{array}$} & \multirow{2}{*}{$\mathrm{T}$} & \multirow{2}{*}{ Sig. } \\
\hline & & B & $\begin{array}{l}\text { Std. } \\
\text { Error }\end{array}$ & & & & & & \\
\hline \multirow{2}{*}{1} & (Constant) & 2.139 & 0.5 & & & & & 4.276 & 0.000 \\
\hline & $\mathrm{EP}-\mathrm{EA}$ & 0.378 & 0.111 & 0.349 & $.349^{\mathrm{a}}$ & 0.121 & 0.111 & 3.408 & 0.001 \\
\hline \multirow{2}{*}{2} & (Constant) & 1.682 & 0.411 & & & & & 4.09 & 0,000 \\
\hline & EA-IEO & 0.533 & 0.103 & 0.493 & $.493^{\mathrm{a}}$ & 0.243 & 0.234 & 5.195 & 0.00 \\
\hline \multirow{2}{*}{3} & (Constant) & 1.154 & 0.516 & & & & & 2.238 & 0.028 \\
\hline & EP-IEO & 0.59 & 0.114 & 0.491 & $.491^{\mathrm{a}}$ & 0.241 & 0.232 & 5.16 & 0.000 \\
\hline
\end{tabular}

Source : Data Processed 2020

\section{Entrepreneurial Passion and Entrepreneurial Alertness}

Table 2 (model 1) revealed that the entrepreneurial passion (EP) coefficient number is positively marked at 0.378 . Each 1 unit increase in entrepreneurial passion then entrepreneurial alertness variable will increase by 0.378 . To find out if there is a significant influence between individual variables is done using statistical tests. Furthermore, 11.1 percent of entrepreneurial alertness can be explained by entrepreneurial passion. The significance level of each independent variable exists at the $\alpha$ level $=0.05$. When viewed from the desired level of significance: the significance of $0.001<0.05$, partially entrepreneurial passion has a positive and significant effect on the entrepreneurial alertness of Muslimah entrepreneurs. Thus the first hypothesis of research can be proven. It is proved that there is a positive and significant influence between entrepreneurial passion and entrepreneurial alertness.

After marriage, women engage in different roles and tasks. The double duties of women which still often debated is whether women should have a career or focus on taking care of the family. Some people argue that there is no need to work after marriage to protect women's rights and obligations as mothers and wives. But women certainly have a very strong reason why they choose as career in the middle of role as wife or mother. There is an obligation to look after and care for the family but the desire to earn their own income also encourages women to pursue careers as entrepreneurs. Indonesia is one of the countries in Southeast Asia that has the largest number of entrepreneurial women. According to the Global Entrepreneurship Monitor Report 
(2019), the level of equality of women and men in Indonesia in entrepreneurship is among the highest in the Asia Pacific region. It was 1.01 up from 0.69 the previous year. Percentage of women employed by 14.1 percent from the total women adult population.

Women as one of the human resources owned by each country, should be used as one of the mediators of economic growth and development through entrepreneurship. Economic development cannot be achieved without participation of women in all aspects of life. The unique and distinctive character of a woman makes women potentially to be entrepreneurs. (Miftakhuljanah et al 2016). Cardon et al (2012) observed that success in the launch of new products and services can be achieved because it is driven by passion. Muslimah entrepreneurs who have a passion for entrepreneurship are entrepreneurs who are happy with their identity as founders and consider that being a founder is an important part of themselves. Understanding the drivers relevant to identify entrepreneurial passion is important since a new business's oportunity do not emerge accidentally but the result of intentional and specific choices. Muslimah entrepreneurs with a powerful entrepreneurial passion are motivated to take advantage of their present knowledge and information. Robert and Locke (2004) mentioned that knowledege though experience expected to achieve successfulness. The result of this study supported by Meirieska and Meiyanto's research (2017) which stated that when entrepreneurs engage in passion recognition of opportunities, missions, visions, decisions, perseverance, and planning processes. Smilor (1997) spoke of their own passion, being able to bring sparks inside a person to make something impossible being possible. There is entrepreneurial alertness to muslimah entrepreneurs who have an entrepreneurial passion. Alertness in Muslim entrepreneurs will be able to identify opportunities that others do not know or ignore.

\section{Entrepreneurial Alertness and Islamic Entrepreneurial Orientation}

From table 2 (model 2), it is known that entrepreneurial alertness (EA) is positively marked with a regression coefficient of 0.533 . Every 1 unit increase in the variable then the variable orientation of Islamic entrepreneurship will increase by 0.378 . Furthermore, based on the results shown in table 2, it is known that the ability of entrepreneurial alertness to explain the entrepreneurial orientation of Islam amount to 0.234. about 23.4 percent of Islamic entrepreneurial orientation can be explained by entrepreneurial alertness. Statistical tests are needed to determine the influence between the two variables studied. These results show that the entrepreneurial alertness of Muslimah entrepreneurs has a positive and significant influence on the Islamic entrepreneurial orientation (IEO). The significance level of the independent variable exists at the level of $\alpha=0.05$. If viewed from the significance level of $0.001>0.05$ can be concluded $\mathrm{H} 0$ is rejected. In part, entrepreneurial alertness has a significant positive influence on the Islamic entrepreneurial orientation of Muslimah entrepreneurs. Furthermore, it can be concluded that hypothesis 2 can be proven. It is proved that there is a positive and significant influence between enrepreneurial alertness and Islamic entrepreneurial orientation.

Uncertainty in entrepreneurship is an inevitable one. It is necessary to know the mental attitude that confronts the situation that is going on in the face of it and what will happen in the future. In Islam, entrepreneurial activities are common, both in terms of concept and practice. Although Islam does not give an explicit explanation about entrepreneurship's concept and practice, they are has a very close in spirit or soul. Islam not only talks about entrepreneurship as a concept but directly practices it in real life in the form of trade. Trading is a noble work in 
Islam because it trades more to the form of worship to Allah SWT. Whatever we do must have the intention to worship in order to have a blessing. In conducting trade, Muslimah entrepreneurs must be alert to opportunities. Previous researches have revealed several ways to identify business opportunities by finding new information, finding relationships for each information and evaluating new information (Tang et al, 2012 and Fatoki \& Oni, 2012). The results of research from Turner and Hendry (2017) showed that alertness of how consumers view innovation and have a direct impact on how innovation is marketed and communicated to consumers. Alertness will be done with the planning.. Entrepreneurs should have a sensitivity in entrepreneurship taking into account defensive or offensive attitudes. If a defensive attitude is chosen, the entrepreneur will think of strategies, tactics, and action plans that are avoiding, preventing, deflecting, covering up, or minimizing things that harm organization. If the offensive attitude is chosen, the entrepreneurs will try to see the advantages that can gain from something he suspects will happen.

\section{Entrepreneurial Passion dan Islamic Entrepreneurial Orientation}

From table 2 (model 3), data processing results are obtained to see the influence of entrepreneurial passion on islamic entrepreneurial orientation. The regression coefficient is worth 0.590 . Every increasing 1 unit then the variable orientation of Islamic entrepreneurship will increase by 5.90 percent. Furthermore, the entrepreneurial passion able to explain the variable Islamic entrepreneurial orientation amounts to 0.232 . That is, 23.2 percent of Islamic entrepreneurial orientation can be explained by entrepreneurial passion while the rest is explained by other variables excluded. The Statistical test uses to find out if there is a significant influence between individual variables. The significance level of the independent variable exists at the level of $\alpha=0.05$. If viewed from a level of significance of 0.00 can be concluded $\mathrm{H} 0$ is rejected. This means, partially variable entrepreneurial passion positively and significantly influences the Islamic entrepreneurial orientation in Muslimah entrepreneurs. It can be concluded that hyphothesis 3 was proven.

Entrepreneur passion motivates entrepreneurs to recognize opportunities and create new businesses (Mjurnieks, 2014 ; Karimi, 2019). It creates new business needs innovation, autonomy and the ability in taking a risk. Turner and Hendry's research (2017) mentioned that a passion for entrepreneurship has different values and opportunities between passionate entrepreneurs and unpassionate ones Getting to know entrepreneurial desires will have consequences for both entrepreneurs and customers. A person who has a passion is able to perform higher than a person who has no passion. Entrepreneurs who have passion are entrepreneurs who feel happy to have an identity as the founder of the business and consider that being the founder of a business is an important part of themselves. Passion forms a desire to behave and act entrepreneurially, and binds entrepreneurs to achieve entrepreneurial goals. Passion is an emotion that influences the recognition of opportunities, missions, visions, decisions, perseverance, and entrepreneurial planning processes. Passion can prevent early-stage entrepreneurs from leaving or leaving their businesses (Wicker \& Davidson, 2015). For Muslimah passion entrepreneurs have a big role in the establishment of awareness business and other efforts. Passionate muslimah love of work is related to the self-efficacy of entrepreneur. It supported by the research of Karimi (2019) that entrepreneurial passion through its elements of intensely positive feelings associated with important identity centrality, is a key motivational factor in entrepreneurial orientation. 


\section{CONCLUSION}

Entrepreneurial passion has a positive and significant influence on entrepreneurial alertness and Islamic orientation entrepreneurship, whereas entrepreneurial alertness also has a positive and significant influence on Islamic entrepreneurial orientation. When Muslimah entrepreneurs show passion towards entrepreneurial orientation activities, they show positive attitude towards entrepreneurial tasks itself.. Entrepreneurial passion has been found to improve competence and Muslimah entrepreneur's passion is proven to encourage alertness to strengthen orientation entrepreneurship and muslimah entrepreneurs need to shape alertness in order to identify opportunities around them to improve entrepreneurial orientation. With certain strategies, it is expected to further increase the entrepreneur orientation continuously and strengthen the entrepreneurial spirit so as to increase business performance. Further study related to Islamic orientation entrepreneurship still needs to be observed in future especially in terms business performance of Muslimah entrepreneur.

\section{ACKNOWLEDGEMENT}

We would like to say thank you to The Research and Community Service Institute and ]to Universitas Jambi to fund this research.

\section{REFERENCES}

Biraglia, A. \& Kadile, V (2016). The Role of Entrepreneurial Passion and Creativity in Developing Entrepreneurial Intentions: Insights from American Homebrewers. Journal of Small Business Management 2016 00(00), pp. 00-00 doi: 10.1111/jsbm. 12242

Boohene, R. (2018). Entrepreneurial orientation, Strategic Orientation and Performance of Small Family Firms in The Kumasi Metropolis. Academy of Entrepreneurship Education Volume 24, Issue 2, 20181 1528-2686-24-2-152.

Cardon, M. S., D. A. Gregoire, C. E. Stevens, \& P. C. Patel (2012). "Measuring Entrepreneurial Passion: Conceptual Foundations and Scale Validation," Journal of Business Venturing 28(3), 373-396.

Cardon, M. S., J. Wincent, J. Singh, \& M. Drnovsek (2009). "The Nature and Experience of Entrepreneurial Passion," Academy of Management Review 34(3), 511-532.

Chen, Y., Zhou, X., Yang, G., Bao, J \& Wang, G. (2017). Social Networks as Mediator In Entrepreneurial Optimism and New Venture Performance. Social Behavior and Personality, 2017, 45(4), 551-562.

Chowdhury, A.J.M.N. (2008), "Towards an Islamic model of entrepreneurship", in Loqman, M. (Ed.), Management Islamic Perspective, BIIT, Dhaka, pp. 6-1

Costa, S.F., Santos, S.C., Wach. D \& Caetano, A. (2017). Recognizing Opportunities across Campus: The Effects of Cognitive Training and Entrepreneurial Passion on the Business Opportunity Prototype. Journal of Small Business Management. doi: 10.1111/jsbm.12348

Fatoki, O. \& Oni, O.A. (2015) The Impact of Entrepreneurial Alertness on the Performance of Immigrant-owned Enterprises in South Africa, Journal of Economics, 6:3, 219-225

Gupta, N., \& Mirchandani, A. (2018). Investigating entrepreneurial success factors of womenowned SMEs in UAE. Management Decision, 56(1), 219-232.

Hoque, N., Mamun, A. \& Mamun, A.M.A (2014)/ Dynamics and traits of entrepreneurship: an Islamic approach. World Journal of Entrepreneurship, Management and Sustainable Development Vol. 10 No. 2, 2014 pp. 128-142 
Huyghe, A., M., Knockaert, \& Obschonka. (2016). "Unraveling the "passion Orchestra" in Academia." Journal of Business Venturing 31 (3): 344-364

Karimi, S. (2019): The role of entrepreneurial passion in the formation of students' entrepreneurial intentions, Applied Economics, DOI: 10.1080/00036846.2019.1645287

Koudstaal, M., Sloof, R., \& Van Praag, M. (2015). Are entrepreneurs more optimistic and overconfident than managers and employees? (Discussion Paper 15-124/VII, Tinbergen Institute, Amsterdam, The Netherlands). https://doi.org/bhrz

Kreiser, P.M \& Davis, J. (2010). Entrepreneurial Orientation and Firm Performance The Unique Impact of Innovativeness, Proactivenee and Risk Taking. Journal of Small Business and Entrepreneurship. Vol.23,No.1.

Lee, K., Kim, Y \& Koh, D (2016): Organizational learning, top management team's entrepreneurial alertness, and corporate entrepreneurship in high-tech firms, Asian Journal of Technology Innovation, DOI: 10.1080/19761597.2016.1249381

Mahmood, R \& Hanafi, N. (2013). Entrpreneurial Orientation and Business Performance of Women-Owned Small and Medium Enterprises in Malaysia:Competitive Advantage as a Mediator. International Journal of Business and Social Science. Vol.4,No.1.

Merieska, M.P \& Meiyanto, I.S (2017). Passion Berwirausaha Pada Pengusaha Muda. Gadjah Masa Journal Of Psychology. Volume 3, NO. 1, 2017: 13-24.

Miftakhuljanah, O, Priatna, W.B \& Suharno (2016). Karakter Wanita Wirausaha Pada Indistri Kecil Kerupuk Kemplang Di kabupaten Ogan Ilir. Jurnal Agribisnis Indonesia (Vol 4 No 2, Desember 2016); halaman 123-136

Murnieks, C. Y., E. Mosakowski, \& M. S. Cardon. (2014). "Pathways of Passion: Identity Centrality, Passion, and Behavior among Entrepreneurs." Journal of Management 40 (6): 1583-1606

Octavia, A \& Hapszi, A (2017). The Model of Market Orientation, Entrepreneurial Orientation and Business Performance of Small Medium Entreprises. International Review of Management and Marketing.Vol 7(3). 331-337

Rauch, A., Wiklund, J., Lumpkin, G.T. \& Frese, M. (2009). Entrepreneurial orientation and business performance: An assessment of past research and suggestions for the future. Entrepreneurship Theory and Practice, 33(3), 761-787.

Robert, B. J., \& Locke, E.A (2004). The Relationship of Entrepreneurial Traits, Skill, and Motivation to Subsequent Venture Growth. Journal of Applied Psychology 89 (4): 587

Sarfaraz, L., Faghih, N. \& Majd, A.A (2014). The relationship between women entrepreneurship and gender equality. Journal of Global Entrepreneurship Research 2014, 2:6 http://www.journal-jger.com/content/2/1/6.

Smilor, R. W. (1997). Entrepreneurship: Reflections on a subversive activity. Journal of Business Venturing, 12(5), 341-346

Tang J, Kacmar K, Busenitz L 2012. Entrepreneurial alertness in the pursuit of new opportunities. J of Bus Vent, 27(1): 77-94.

Tejada., J.J \& Punzalan, J.R.B (2012). On the Misuse of Slovin's Formula Jeffry J. Tejada and Joyce Raymond B. Punzalan. The Philippine Statistician Vol. 61, No. 1, pp. 129-136.

Turner, T. \& Hendry, S. (2017) Radical innovation and value extraction: the role of the user's entrepreneurial passion on satisfaction with product, firm, and industry, Journal of Small Business \& Entrepreneurship, 29:2, 156-173 
Vallerand, R. J., G. A. Céline Blanchard, R. K. Mageau, C. Ratelle, M. Léonard, M. Gagné, \& J. Marsolais. (2003). "Les Passions De L'ame: On Obsessive and Harmonious Passion." Journal of Personality and Social Psychology 85 (4): 756.

Wicker, C., \& Davidsson, P. (2015). The entrepreneurial break-up: Disengaging from the startup phase. Research Handbook of Entrepreneurial Exit, 197.

Yaacob, Y., \& Azmi, I.A.G (2012). Entrepreneur's of Social Responsibilities From Islamic Perspective : Study Of Muslim Entrepreneurs In Malaysia .8th International Strategic Management Conference. Procedia - Social and Behavioral Sciences 58 ( 2012 ) 1131 1138 . 